$7-2020$

\title{
Digitalization and International Tax Dispute Resolution: A Window of Opportunity for BRITACOM
}

Jinyan Li

Osgoode Hall Law School of York University, jli@osgoode.yorku.ca

Nathan Jin Bao

Osgoode Hall Law School of York University (Student Author)

Shanghua $\mathrm{Hu}$

Wei Hu

Matias Zerbino

Osgoode Hall Law School of York University (Student Author)

Follow this and additional works at: https://digitalcommons.osgoode.yorku.ca/scholarly_works

Part of the Tax Law Commons

\section{Repository Citation}

$\mathrm{Li}$, Jinyan; Bao, Nathan Jin; Hu, Shanghua; Hu, Wei; and Zerbino, Matias, "Digitalization and International Tax Dispute Resolution: A Window of Opportunity for BRITACOM" (2020). Articles \& Book Chapters. 2803. https://digitalcommons.osgoode.yorku.ca/scholarly_works/2803

This Article is brought to you for free and open access by the Faculty Scholarship at Osgoode Digital Commons. It has been accepted for inclusion in Articles \& Book Chapters by an authorized administrator of Osgoode Digital Commons. 
Li et al Digitalization and Dispute Resolution (C2020

\title{
Digitalization and International Tax Dispute Resolution: A Window of Opportunity for BRITACOM
}

Jinyan Li, Nathan Jin Bao, Shanghua Hu, Wei Hu and Matias Zerbino *

\begin{abstract}
*Jinyan Li, Professor, Osgoode Hall Law School of York University, Canada (Osgoode); Nathan Jin Bao is a JD student at Osgoode; Shanghua Hu and Wei Hu are visitors at Osgoode and on a study leave from the State Taxation Administration; Matias Zerbino is a LLM Tax student at Osgoode and tax lawyer from Brazil.
\end{abstract}

This paper has been submitted for publication in BRITJ.

\begin{abstract}
:
Digitisation technologies are facilitating and transforming tax administration and dispute resolution in various ways. This paper presents some existing and emerging best practices in digitalized tax administration and smart dispute resolution. Inspired by the objectives of the Belt \& Road Initiative and BRITACOM and these best practices, this paper suggests that BRITACOM take advantage of digitisation and seize upon the unprecedented opportunity to create a digitalized mechanism for resolving cross-border tax disputes among Belt \& Road jurisdictions.
\end{abstract}

Key words: digitisation, tax dispute, arbitration, online ADR, mutual agreement procedure (MAP), BRITACOM, Belt and Road Initiative

\section{Introduction}

In the age of digitization, digital technologies affect the business of taxpayers and tax administrations by enhancing or transforming how business is done. ${ }^{1}$ Taking advantage of digital technologies to reduce the costs of tax compliance and administration and to expedite tax dispute resolution are among the priorities for BRITACOM (Belt and Road Initiative Tax Administrations Cooperation Mechanism) - an organization established in 2019 by tax administrations in over 30 Belt and Road Initiative (BRI) jurisdictions. ${ }^{2}$ In this paper, we consider the recent developments and best practices in the digitization of tax administration and dispute resolution and suggest that BRITACOM consider establishing a technology-enhanced mechanism for minimizing and resolving cross-border tax disputes.

Digital technologies are reshaping or creating new ways of communicating, working and transacting. ${ }^{3}$ Notable examples are the expansion of the Internet, the Internet of Things, the availability of portal solutions, social media, mobile platforms, cloud computing, big data technologies and advanced analytics techniques, Blockchain, as well as artificial intelligence (AI), 
including machine learning. New business models enabled by digital technologies challenge the application of existing international tax rules (such as the basis for allocating taxation rights among countries based on the source of income and residence of taxpayers as well as transfer pricing rules), giving rise to potential international tax disputes. It is encouraging to witness the global efforts on developing a consensus on digital taxation and reducing base-erosion and profit shifting. ${ }^{4}$ Our paper does not engage in the substantive tax issues. Instead, the paper focuses on the use of digital technologies in tax disputes prevention and resolution.

Following this Introduction, Part 2 canvases some existing and emerging practices in digital tax administration and digital or "smart" dispute resolution. It highlights the point that some developing countries are leaders in the digitalization movement and the speed of digitalization is getting faster. There is also an increasing level of standardization in technologies used by taxpayers and tax administrations across jurisdictions. Part 3 presents the types and nature of international tax disputes among BRI countries. It suggests that technology has come to the aid of tax administrations in the sense of overcoming imperfect taxpayer information problem and enabling tax administrations in developing countries to leapfrog to the digital age. Part 3 then explores the potential application of digital technologies in reducing and resolving tax disputes in BRI jurisdictions through advanced rulings, settlement or mutual agreement procedure (MAP). It suggests that the extent of benefits would depend on whether a tax dispute is largely quantifiable (such as transfer pricing), measurable (such as temporal test in defining a service permanent establishment), or mostly interpretative (such as characterization issues or treaty-abuse issues). Inspired by the recent developments in digitalization in tax administration and dispute resolution, Part 4 presents reasons for BRITACOM to create a dispute management mechanism in order to expedite resolution of cross-border tax disputes while enhancing the capacity of tax administrations and improving taxpayer services.

\section{Digitalizing Tax Administration and Dispute Resolution: Selected Practices and Experiences}

\subsection{The Trend of Digitalization}

Digitization refers to the conversion of text, pictures, or sound into a digital form that can be processed by a computer. The technologies of digitization originally enable the conversion of traditional forms of information storage such as paper and photographs into the binary code (1s and 0s) of computer storage. Increasingly, technologies allow data to be created, stored, communicated and consumed digitally. Business enterprises, institutions and government agencies have been going through a digital transformation, turning digitization into new processes, activities, and transactions. Some recent technologies, such as Big Data, ${ }^{5}$ Blockchain, ${ }^{6}$ and $\mathrm{AI}^{7}$ (such as deep machine learning $^{8}$ ) are regarded as disruptive as they significantly affect the way that consumers, businesses and government agencies operate. The OECD/G20 Base Erosion and Profit Shifting Project notes: ${ }^{9}$

Ubiquitous digital devices, connectivity and "smart" technology are bringing significant changes that are profoundly affecting relationships and markets. ICT [Information communication technology] has become part of the foundational infrastructure for business and society, evidenced in a heavy reliance on efficient and widely accessible online communication networks and services, data, software, and hardware. 
Disruptive technologies challenge the adequacy of existing international tax rules and traditional tax administration procedures and practices while generating new opportunities for policymakers and tax administrations. Technologies also disrupt how international commercial disputes are generated, managed and resolved. More and more commercial arbitrations and litigation take place primarily by means of electronic communication, and e-filing in courts around the world has become more commonplace in recent years. There are some pilot projects that experiment with "smart” or "automatic" resolution by using AI technologies.

\subsection{Tax Administration}

\subsubsection{The Problem of Imperfect Information and digitalization}

"At the core, modern revenue bodies are data processing organisations and, as such, they are vulnerable to disruptive ICT innovations." ${ }^{10}$ At the same time, digital technologies offer the promise of addressing the problem of imperfect information facing tax administrations. ${ }^{11}$ Taxpayer information can be imperfect because taxpayers may misrepresent their incomes, consumption or other taxable events to avoid or even evade paying taxes. Tax administrations are often constrained from obtaining information or have to use resource-heavy tax audit processes to verify information. Digitalization can help alleviate these constraints in several ways:

a) Better ways of verifying taxpayer information. Information reported by taxpayers can be checked automatically and more accurately by tax administration's computers. Tax authorities are using real-time or near real-time data analytics engines to validate invoices and lag discrepancies, verify sales and purchase declarations, verify payroll and withholding declarations and compare data across jurisdictions and taxpayers. Based on these analyses, tax authorities make determinations, including tax and audit assessments.

b) Obtaining taxpayer information from third parties (such as users of platforms) as well as tax administration in other countries (such as through automatic information exchange mechanism). With data being collected in more standardized formats, increased processing capabilities have allowed tax authorities to assess taxpayer risks by analyzing large data sets and by combining different sources of data. Tax administrations can draw on information from a wide range of government and corporate sources, as well as individual digital footprints, to create a profile of each taxpayer's total income.

c) Accuracy of information can be enhanced through using blockchain technology. When the risk of providing inaccurate information is exposed, taxpayers' compliance in reporting and filing is expected to improve.

As such, digital technologies can potentially make taxpayer information more transparent to tax administrations. They enable tax administrations to have a clearer window into a taxpayer's tax operations, to use smarter tools (such as advanced analytics and AI) to monitor consistency, track compliance and more precisely choose audit targets. Such enhanced scrutiny and unprecedented visibility are likely to lead to more effective tax administration, higher tax assessments, leading to more tax controversy. ${ }^{12}$

Many countries have implemented some form of digital tax reporting or collection requirements and many of those early movers are developing nations. ${ }^{13}$ Some examples are: in 2008, Brazil 
introduced requirements for real-time e-invoicing and e-reporting; in 2011, Mexico required companies to integrate their financial systems with the host tax authority in order to share VAT activity in real time. In some countries, digital tax administration is part of constructing a digital society. Estonia is an example. ${ }^{14}$ Estonia's digital society is built on electronic identity system (eID) and a data exchange layer called the $\mathrm{X}$ road. All residents have ID cards that serve as mandatory identity documents and used for authentication for different digital services and digital signatures. The $\mathrm{X}$ road is a form of digital infrastructure, a secure data exchange layer for residents, public institutions, and private companies. It enables a secure Internet-based data exchange between information systems. The government offers e-services to its residents, including filing tax returns. In 2016 Estonia introduced VAT Appendix process, under which all businesses must submit data of all transactions starting from $1000 €$. The tax administration thus gets data from both parties of a transaction. Data is submitted with the monthly VAT return either through user interface (e-tax IT system) or by machine to machine interface between the tax administration IT system and businesses' systems.

\subsubsection{E-filing and Pre-populated Tax Returns}

Digitalization occurs at various stages of tax compliance and administration. The level of digitisation in tax administration in Latin American countries is shown in the table below: ${ }^{15}$

\begin{tabular}{|c|c|c|c|c|c|c|c|c|c|}
\hline Parameters & Argentina & Brazil & Chile & Colombia & $\begin{array}{c}\text { Costa } \\
\text { Rica }\end{array}$ & Mexico & Panama & Peru & Uruguay \\
\hline \multicolumn{10}{|l|}{ 1. Level of digitalization } \\
\hline 1. E-invoicing & $x$ & $\mathrm{x}$ & $x$ & $x$ & $x$ & $\mathrm{x}$ & & $x$ & $\mathrm{x}$ \\
\hline 2. Electronic filing of tax returns & $\mathrm{x}$ & $\mathrm{x}$ & $\mathrm{x}$ & $\mathrm{x}$ & $\mathrm{x}$ & $\mathrm{x}$ & $\mathrm{x}$ & $\mathrm{x}$ & $\mathrm{x}$ \\
\hline 3. Electronic filing of TP documentation/TP returns & $x$ & $x$ & $x$ & $x$ & & $x$ & $\mathrm{x}$ & $x$ & $x$ \\
\hline 4. Electronic communication with tax authorities & $\mathrm{x}$ & $\mathrm{x}$ & $\mathrm{x}$ & $\mathrm{x}$ & $x$ & $\mathrm{x}$ & $\mathrm{x}$ & $\mathrm{x}$ & $\mathrm{x}$ \\
\hline $\begin{array}{l}\text { 5. Exchange of information between tax authorities } \\
\text { (local, regional, federal) }\end{array}$ & $\mathrm{x}$ & $\mathrm{x}$ & $\mathrm{x}$ & $\mathrm{x}$ & $\mathrm{x}$ & $\mathrm{x}$ & $x$ & $\mathrm{x}$ & $\mathrm{x}$ \\
\hline \multicolumn{10}{|l|}{$\begin{array}{l}\text { 2. Functionalities of softwares/tools implemented by } \\
\text { Tax Authorities }\end{array}$} \\
\hline 1. Data collection and standardization of formats & $x$ & $\mathrm{x}$ & $\mathrm{x}$ & $\mathrm{x}$ & $x$ & $\mathrm{x}$ & $x$ & $\mathrm{x}$ & $\mathrm{x}$ \\
\hline 2. Audit trails with external data & $\mathrm{x}$ & $\mathrm{x}$ & $\mathrm{x}$ & $\mathrm{x}$ & & $\mathrm{x}$ & & & $\mathrm{x}$ \\
\hline 3. Audit trails with internal data & $x$ & $x$ & $x$ & $x$ & & $x$ & $x$ & $x$ & $x$ \\
\hline 4. Generation of outliers & $x$ & $x$ & & $x$ & & $x$ & & $x$ & $x$ \\
\hline 5. Electronic interaction with taxpayers & $x$ & $x$ & $x$ & $x$ & $\mathrm{x}$ & $x$ & $\mathrm{x}$ & $x$ & $x$ \\
\hline \multicolumn{10}{|l|}{ 3. Data Analytics } \\
\hline 1. Standardization of data gathering (i.e. Xml-schema) & $x$ & $\mathrm{x}$ & $\mathrm{x}$ & $\mathrm{x}$ & $\mathrm{x}$ & $\mathrm{x}$ & $\mathrm{x}$ & $\mathrm{x}$ & $\mathrm{x}$ \\
\hline $\begin{array}{l}\text { 2. Automatic generation of calculations and/or } \\
\text { penalties }\end{array}$ & $\mathrm{x}$ & $\mathrm{x}$ & $\mathrm{x}$ & $\mathrm{x}$ & & $\mathrm{x}$ & $\mathrm{x}$ & $\mathrm{x}$ & \\
\hline 3. Reconciliation with historical data & $\mathrm{x}$ & $\mathrm{x}$ & $\mathrm{x}$ & $\mathrm{x}$ & & $\mathrm{x}$ & & $\mathrm{x}$ & $\mathrm{x}$ \\
\hline 4. Generation of outliers cross-checked with tax returns & $\mathrm{x}$ & $\mathrm{x}$ & $x$ & $\mathrm{x}$ & & $x$ & & $x$ & $\mathrm{x}$ \\
\hline $\begin{array}{l}\text { 5. Exchange of information regarding data analytics } \\
\text { with taxpayers }\end{array}$ & & $\mathrm{x}$ & & $\mathrm{x}$ & & & & & \\
\hline \multicolumn{10}{|l|}{ 4. Exchange of information at the international level } \\
\hline 1. Country-by-Country reports (MCAA) & $x$ & $x$ & $\mathrm{x}$ & $x$ & & $x$ & $x$ & $x$ & $\mathrm{x}$ \\
\hline 2. Financial information (CRS, FATCA) & $x$ & $x$ & $\mathrm{x}$ & $x$ & & $x$ & & $x$ & \\
\hline 3. Rulings and APAs & $x$ & & & & & $x$ & & & $x$ \\
\hline 4. Mutual Agreements for cooperation in Tax matters & $x$ & $\mathrm{x}$ & $\mathrm{x}$ & $\mathrm{x}$ & $x$ & $\mathrm{x}$ & $\mathrm{x}$ & $\mathrm{x}$ & \\
\hline 5. Mutual Agreements for Criminal purposes & & $\mathrm{x}$ & & & & $\mathrm{x}$ & & $\mathrm{x}$ & \\
\hline
\end{tabular}


Some countries have experimented with pre-filing of tax returns. Denmark pioneered this initiative in 1988. Pre-populating tax returns simplifies tax filing and payment for taxpayers as tax return is pre-filled with information obtained by the tax administration from third parties. This may ultimately lead to real-time taxation, eliminating the need for annual tax returns. ${ }^{16}$

Mobile app has been used in some countries to facilitate taxpayer services and tax payment. For example, the Chinese State Taxation Administration (STA) released an Individual Income Tax App in 2019 to enable taxpayers to file their tax returns with pre-populated forms on the App. ${ }^{17}$ The e-Renta (electronic income tax) application in Chile is described as follows: ${ }^{18}$

[It] facilitates and fosters the voluntary filing of income tax returns. The app allows taxpayers to view and accept their proposed income tax statement, which is based on thirdparty information, including refund information. This is especially useful for taxpayers who have a simple tax situation (such as independent workers or dependent workers with tax benefits who request tax refunds). The app also allows taxpayers to check the status of the income statement and to know if refund requests have been accepted. The declaration process was simplified in the design of the app: entry of the taxpayer's secret code, review of the amount to be paid or the refund request, entry of bank account details and acceptance of the proposal. More than 170000 taxpayers have downloaded the application and more than 120000 taxpayers filed the declaration by this means.

\subsubsection{E-invoicing}

E-invoicing has also been widely adopted. Some tax administrations are exploring the potential advantages of blockchain technology. This technology offers transparency and confidentiality that could equip tax administrations with the necessary tools to tackle the problems of international tax compliance through sharing sensitive information between tax administrations. The tax administration in the city of Shenzhen, China introduced a pilot Blockchain electronic invoice system in 2018. Since then, blockchain invoices have been widely used in finance, retailing, hotel catering, and parking services by over 7,000 companies. ${ }^{19}$

E-invoicing has also been implemented in other countries, such as Chile, Italy, Peru and Russia. For example, the mandatory online cash registers in Russia record information on each transaction, which is then transferred immediately to a server where tax authorities can access it and crosscheck the information. ${ }^{20}$ This process is described as follows in the OECD Report:

Such registers instantly upload sales data to the tax administration's data processing centres. The data produced by the OCR system enables new types of audit activities that give the tax administration the authority to automatically monitor transactions, analyse data, monitor the use of cash registers and inspect them remotely. As required by legislation, each receipt generated by online cash registers has a QR code that enables customers to verify the transaction by comparing it to the information maintained by the tax administration. $^{21}$

\subsubsection{E-withholding of Taxes}

The Netherlands tax administration created a design for a new payroll tax platform by applying blockchain technology to payroll tax. ${ }^{22}$ Under this design, the employer (who used to act as withholding agent) is removed as an intermediary by embedding smart contracts, which consist of 
agreements that execute themselves autonomously without third party. More details are explained below:

... [T] [he employer and employee come to an agreement based on data and terms. When both parties validate the agreement, it will be registered in a decentralised blockchain in which the tax administration is present. When the employer makes the gross payment into the system it would be the end of the process for him. Within the system tax data is matched with the payment using smart contract technology to calculate the correct tax and social security due and only the net payment goes to the employee, whilst the government automatically collects the tax. As a result, transaction time and costs are greatly reduced, as well as opportunity for employers to use payroll taxes to ease their cashflow problems is removed. Because of the use of smart contracts the transactions is also considered to be very reliable. $^{23}$

The platform economy or sharing economy generates and records large volumes of consumption and income data that can be accessed by tax administrations to improve tax collection. For example, Estonia uses the platform technology to connect Uber drivers directly with the tax office, adding income from rides directly to their tax return. ${ }^{24}$

\subsubsection{E-detection of Tax Fraud and Audit Risks}

As more and more data from different sources can be integrated, it has become easier for tax administrations to use AI, data analytics and data mining technologies to detect tax fraud. For example, it has been reported that an AI engine has been embedded in the heart of the Golden Tax System, the software used by the Chinese STA. ${ }^{25}$ The AI can flag more than 95 per cent of offences by connecting all government databases, including property, commodities, international trade and business registration and automatically detect if companies and individuals have reported false data and spot evasion methods not previously known to tax authorities. At the time of reporting (February 2020), this program has not been implemented. Singapore uses vehicle records and employee Central Provident Fund contribution data to help determine whether a company has a business presence, thus indicating if it is active or dormant. ${ }^{26}$

Increasingly sophisticated use of analytics on expanding data sets is leading to a sharpening of risk management and the selection of a range of intervention actions, including through automated processes. For example, the Chinese STA has introduced a cloud-based big data platform. "The platform has so far collected four main types of core business data covering: individual income tax administration; VAT invoices; export tax rebates; external data and historical data. The total number of database tables exceeds 200 000. This data is applied within 264 data models to manage risk." ${ }^{27}$

In the case of large taxpayers, cooperative compliance approaches are hugely enhanced by technology. The OECD, Tax Administration 2019 gives the practices of China and Estonia, among others, as examples: ${ }^{28}$

In China, the large Business Department (IBD) at the STA's headquarters conducts risk management of over 1000 large business taxpayers through the use of big data, risk analysis, risk response and feedback. The IBD has designed a series of risk identification indicators and models for computers to rate and identify risks and draft risk identification reports automatically, with the models updated based on experience. In terms of large 
taxpayer service, differentiated management strategies and tailored services have been developed, including improving tax certainty, enhancing co-operation between large taxpayers and tax authorities and providing risk related services for specific industries. STA has also set up a new service targeted at large business restructuring, which usually involves multiple regions and tax types. This new service will help to co-ordinate and resolve difficult tax matters in large businesses' restructuring processes based and thus improve tax certainty and consistency in implementation.

In Estonia, the Estonian Tax and Customs Board (ETCB) is developing a new e-service Tax Behaviour Information. Data on turnover, number of employees, average salary, tax debts, shortcomings in complying with tax law, background of the management and other information will be used as an input to a number of risk criteria. A tax compliance rating will then be calculated, including the risk of tax audit for each legal person registered in Estonia. Taxpayers will be able to see themselves and their business partners through the eyes of the ETCB as well as to compare themselves with their peers. (Initially, the taxpayer will see only his own ratings along with the explanations of possible shortcomings in complying with tax law. The taxpayer then will be able to address those shortcomings to improve his ratings.) The taxpayer can share his ratings with other users of the service so that they can assess whether his tax affairs are in order, helping to incentivise compliant behaviour.

\subsubsection{Global Automatic Exchange of Information and Transfer Pricing Reporting}

Digital technologies and newly-developed international frameworks enable enhanced international exchanges of data. Two notable examples are the Common Reporting Standard (CRS) and Country by Country Reporting (CbCR), which are massively increasing the quantity of data available on international activity and providing useful information for audit and case selection processes, or even pre-filling of tax returns in some countries.

The new global standard on Automatic Exchange of Information (AEOI) - the CRS which together with the United States Foreign Account Tax Compliance Act (FATCA) provides for the exchange of non-resident financial account information with the tax authorities in the account holders' country of residence. ${ }^{29}$ The CRS asks jurisdictions to obtain information from their financial institutions and automatically exchange that information with other jurisdictions on an annual basis. It sets out the financial account information to be exchanged, the financial institutions required to report, the different types of accounts and taxpayers covered, as well as common due diligence procedures to be followed by financial institutions. ${ }^{30}$ Since the first exchanges taking place in September 2017 involving around 50 jurisdictions, more than 100 jurisdictions now exchange information on financial accounts under the CRS annually.

Country-by-country reporting (CbCR) was a minimum standard adopted under Action 13 of the BEPS Project. Under this standard, all large MNEs (MNEs with revenue in excess of $€ 750$ million) are required to prepare a $\mathrm{CbC}$ report with aggregate data on the global allocation of income, profit, taxes paid and economic activity among tax jurisdictions in which it operates. The information included in the CbC Report is collected by the country of residence of the Reporting Entity for the MNE group and is then exchanged in the format of the CbC XML Schema. CbC Reports are electronically transmitted between Competent Authorities in accordance with the CbC XML Schema. ${ }^{31}$ This mechanism assists tax administrations in obtaining a complete understanding of 
the way in which MNEs structure their operations, by annually providing them with key information on the global allocation of income and taxes paid, together with other indicators of the location of economic activity within the MNE group. It also covers information about which entities do business in a particular jurisdiction and the business activities each entity engages in. Data harmonization is a key step in the CbCR process.

Tax administrations use CbC reports in high level transfer pricing and base-erosion and profit shifting risk assessments. Over 90 jurisdictions have introduced $\mathrm{CbC}$ reporting filing obligations and over 2400 bilateral relationship exist for the exchange of CbC reports. ${ }^{32}$ With more information available to tax administrations, tax disputes have been rising. ${ }^{33}$

\subsection{Commercial Dispute Resolution}

\subsubsection{Streamlining Processes}

Digitalizing the process of dispute resolution (litigation or alternative dispute resolution or ADR) is occurring at different stages, ranging from evidence-gathering, written proceedings, oral hearings to tribunal decision and award. Unlike CRS and CbCR processes, however, there is no global standard for the technologies facilitating the digitalization. The level of digitization is greater for ADR than court proceedings. Online dispute resolution in the form of robot mediator or machine-mediated communication is emerging. Below are some selected practices to showcase the application of digital technologies.

\subsubsection{E-courts}

Courts are much slower in implementing digital technologies. The general level of digitalization is electronic filing and sharing of documents and scheduling court hearings. ${ }^{34}$ For example, an online document management platform in Ontario, Canada enables parties to submit electronic copies of materials required for a hearing and provides authorized parties with 24/7 instantaneous access to event-related documents. It allows court staff to create workspaces for cases and schedule hearings. $^{35}$

Digitalizing the litigation process (short of judging) can be illustrated by the eLitigation system launched by the Singapore Supreme Court in 2013 to replace an earlier e-filing system. ${ }^{36}$ This program represents a paradigm shift: moving the system from a document-centric filing system to a case-centric litigation system. It is described as a convenient and secure access to the web-based service via Singpass: filing can be completed online or saved for submission at a later time and dynamic electronic court forms replaced PDF documents; it enables online collaboration between law firms and clients through online case file.

In Indonesia, some courts hold hearings online. One example is the Constitutional Court in Indonesia, which can hold online proceedings to determine whether a statute is constitutional. ${ }^{37}$ The Supreme Court of Indonesia issued Regulation 1/2019 to envisage the eventual development of a full-blown electronic court system (including all courts), that is proceedings can be commenced, court fees paid, documents and pleadings submitted, hearings conducted and judgments pronounced electronically. ${ }^{38}$

Using robots as judges is perhaps the most ambitious application of digital technologies in dispute resolution. Estonia initiated a "robot judge" pilot project in 2019 to give algorithm authority to 
adjudicate small claims disputes. ${ }^{39}$ In concept, AI can help improve access to justice in civil cases, however he algorithms used to help recommend criminal sentences in the United States have been criticized for being biased. ${ }^{40}$ Chinese courts use robots as aids to judges and the public. Robots can retrieve case histories and past verdicts, reducing the workload of officials. Some robots are even specialists in areas such as commercial law or labour law. Chinese courts also use AI to sift through private messages or comments on social media that can be used as evidence in court. Traffic police are reportedly using facial recognition technology to identify and convict offenders. $^{41}$

\subsubsection{Online ADR}

International commercial and investor-state arbitrations and other forms of ADR are migrating to online. Earlier online arbitration/mediation procedures applied to resolve disputes arising from ecommerce transactions. ${ }^{42}$ Now, the scope can be extended to general trade disputes and investorstate disputes. ${ }^{43}$ Also, earlier online dispute resolution (ODR) processes simply replicated face-toface dispute resolution approaches online (that is, Internet-aided approaches).

More recent applications enable file-sharing and collaboration. For example, Singapore has established a regional ADR centre and a high-tech facility for international arbitrations that offers the combination of a modern venue with state-of-the-art software and services. Singapore has committed to implementing fully electronic arbitrations, where a master set of digitized arbitration content is provided to each party. ${ }^{44}$ Another example is the SCC Platform launched by the Arbitration Institute of the Stockholm Chamber of Commerce (SCC) in September 2019. ${ }^{45}$ The core of the SCC Platform is a file sharing function, where all case material can be uploaded. The material is organized based on the preference of the arbitrator and parties and it can be viewed on the Platform itself, downloaded or printed. It is also possible to search all material for keywords or phrases. In addition to file sharing, the platform contains a case calendar, overview of all participants in the case, a notice board for tribunal and SCC notices, and a page containing a general overview of the proceedings. All new arbitrations registered with the SCC are assigned a site on the SCC Platform and all communication with the SCC takes place on the platform.

The use of AI or Robots as arbitrators or mediators is increasing. Originally used by digital companies such as eBay and PayPal to resolve online disputes, it has been recently used to resolve disputes that tend to be numeric-based and with minimal emotional complexity. UNCITRAL Arbitration Rules ${ }^{46}$ and the ICC Arbitration Rules ${ }^{47}$ have no stipulation that the arbitrator should be human, which theoretically makes it possible for the parties to nominate a machine arbitrator. An online dispute resolution framework endorsed by APEC in 2019 aims at providing technologyassisted dispute resolution through negotiation, mediation, and arbitration for business-to-business claims. $^{48}$

Under this ODR Framework, a business may file a crossborder complaint online against a business in another participating economy in cases where both businesses have consented to have such disputes resolved under the ODR framework. During the first phase of the procedure, the businesses are allowed to exchange information and proposals, and negotiate a binding settlement of their dispute, through electronic means ("Negotiation Stage”). If the parties cannot reach a binding agreement by amicable negotiations, the relevant ODR provider will appoint a qualified online dispute resolution (ODR) neutral to mediate the dispute (and if possible, reach a binding settlement agreement) ("Mediation Stage") or to arbitrate the dispute (and issue a binding award) (“Arbitration Stage”). The 
use of artificial intelligence or other modern technology is encouraged in any of the three stages. ${ }^{49}$

Robot mediators are already at work. For example, in 2019, a court case was settled in the United Kingdom by using Smartsettle ONE - an ODR tool developed in British Columbia, Canada. ${ }^{50}$ The underlying dispute concerned unpaid fees of approximately 2,000 British pounds, allegedly owed for personal counselling sessions. Smartsettle ONE employs algorithms that learn the bidding tactics and priorities of the parties to a dispute and helps move them towards a settlement. In this particular case, each side assesses what they hope to settle for, as well as what they are willing to settle for and submit their hoped-for resolution as well as a blind bid of their best alternative to non-agreement. Based on each party's input of the range of settlement, the system generates a dollar amount, while favouring the first party to submit a compromise. The system allows both parties to privately make offers and counteroffers by moving flags along sliders showing the other side a green flag, which represents their hoped-for figure, all the while a yellow flag remains hidden (the blind bid). In this particular case, the system allowed the parties to settle their dispute in less than one hour. Where there are quantifiable issues to resolve and the question is simply "how much are you willing to settle for?", this is a helpful tool. ${ }^{51}$

\subsubsection{International Tax Disputes and the Mutual Agreement Procedure (MAP)}

International tax disputes are resolved through MAP. The MAP provision in tax treaties between BRI jurisdictions is based on Article 25 of the OECD Model Tax Convention or the UN Model Tax Convention. ${ }^{52}$ Under Article 25 the competent authorities "shall endeavour" to reach an agreement to settle the "specific-case" disputes as well as "interpretive disputes" (i.e., difficulties or doubts arising as to the interpretation or application of the Convention). Further, the competent authorities may consult together for the elimination of double taxation in cases not provided for in the Convention (i.e., disputes that are of interpretive or even "legislative" nature). Article 25 permits the competent authorities to "communicate with each other directly, including through a joint commission consisting of themselves or their representatives, for the purpose of reaching an agreement.

Arbitration can be used to deal with specific-case disputes, but not interpretive disputes or legislative issues. It is part of MAP. There are two types of arbitration at the moment: "independent opinion" style arbitration (that is, the arbitration panel will issue an independent decision) and a "last best offer" or "final offer" approach (commonly referred to as "baseball arbitration"). Baseball style arbitration is preferred as it is simpler and less costly and is used in US tax treaties. ${ }^{53}$

Neither the standard MAP process nor arbitration process has been highly digitalized. Digitalization seems to be limited to using emails and video conferencing. In fact, "the use of technology has not yet been embraced with respect to international tax dispute resolution." ${ }^{4}$ In the next part of this paper, we will explore the possible ways in which digital technologies can help minimize tax disputes and/or resolve tax disputes in Belt \& Road countries. 


\section{Digital Aids and International Tax Disputes in Belt and Road Jurisdictions}

\subsection{Tax Disputes}

Cross-border tax disputes in Belt and Road countries ${ }^{55}$ are concerned with: transfer pricing (over $20 \%$ of total disputes), withholding taxes (close to 20\% for large corporations), deductions (over $10 \%$ of total disputes), and other issues (such as permanent establishment, general anti-avoidance rule, tax residency, and tax treaty interpretation and beneficial ownership, each of which accounts for less than $5 \%$ of total disputes). ${ }^{56}$

Transfer pricing disputes are the most significant, accounting for $1 / 5$ of total disputes. In comparison, over 55\% of MAP cases reported by the OECD are transfer pricing cases. ${ }^{57}$ Transfer pricing disputes are largely numerical or quantitative as the heart of the dispute lies in the arm's length price. Other disputes generally involve interpretative issues regarding the characterization of income for withholding tax purposes, deductibility of expenses, and meaning of permanent establishment and residency.

According to Thomas, Lai and Kyte, ${ }^{58}$ the main causes of tax disputes are "inconsistent application or interpretations, unclear tax policies and rules, resource constraint, complex administration procedures, insufficient understanding of international tax law, enforcement not in accordance with tax treaties, unintended consequence of domestic practice, inadequate transparency, and other, including non-tax factors."

\subsection{Digitalization as Aid and Equalizer}

Belt and Road jurisdictions presumably have different levels of digitalization in tax administration (or digital maturity) and adopt different standards and regulations for protecting data security and privacy. Such divergence affects the use of technology in resolving international tax disputes. Fortunately, there seem to be favourable conditions and significant scope for technology to play a greater role in improving tax administration and dispute resolution.

As mentioned in Part 2 of this paper, some of the leaders in digital tax administration and dispute resolution are developing or emerging economies. The absence of legacy problems attributable to older technologies makes it easier (and less costly) to establish new ICT infrastructure in developing countries. The deepening penetration of digital technologies in people's daily activities and business models in these countries makes it imperative for tax administrations to provide services to taxpayers digitally. Perhaps a more important reason for developing countries to adopt digital technologies is to detect and prevent tax fraud. E-invoicing, digital payments, and crosschecking taxpayer information enabled by technology help reduce tax leakages as well as minimize corruption..$^{59}$ For developing countries, digitalization may generate additional revenue. One study found that digitalizing government payments in developing countries could save roughly 1 percent of GDP, equivalent to $\$ 220-\$ 320$ billion in value annually. ${ }^{60}$

Technology can also function as an "equalizer" in international tax administration. By participating in the global CRS and CbCR programs, developing countries can benefit from obtaining data that may not be otherwise accessible. With the technical assistance provided by BEPS Inclusive Framework, the Platform for Collaboration on $\operatorname{Tax}^{61}$ - a joint initiative of the IMF, OECD, UN and World Bank Group, BRITACOM, and other organizations, developing countries can expedite 
their digitalization process and upgrade the capacity for administering international tax issues, such as transfer pricing.

\subsection{Potential Digital Aids in Tax Dispute Prevention and Resolution}

\subsubsection{Expediting Settlement and MAP Processes}

Settlement and MAP are the main ways of resolving international tax disputes. According to Thomas, Lai and Kyte, larger corporations tend to settle more disputes while smaller corporations tend to opt for MAP. Large corporations settled about $60 \%$ of disputes and submitted only $11 \%$ of disputes to MAP, while smaller corporations submitted $40 \%$ of disputes to MAP. ${ }^{62}$ The main reasons why a taxpayer opts for settlement as opposed to seeking an appeal (both domestic and MAP) are lengthy process, costs and resource concerns, as well as low confidence in the effectiveness of the appeal processes. For example, more than half of all disputes took more than two years to complete or simply failed to pass the appeal procedure. Taxpayers reported negative experiences in dealing with disputes, including that the tax authority lacked technical knowledge and made unreasonable requests.

Digital technologies can potentially expedite dispute resolution by improving the quality of data and documentation (such as using standardized mechanism for sharing data), reducing the time of communications or the need for face-to-face meetings through video conferencing, improving transparency through using Blockchain, or prioritizing "high risk" files through using Big Data or AI. ${ }^{63}$ Some settlement or MAP may even be facilitated by AI. Specific applications are canvassed below.

\subsubsection{Transfer Pricing and Quantifiable Disputes}

Transfer pricing disputes top the list of international tax disputes. ${ }^{64}$ The main causes of transfer pricing disputes include information asymmetry, insufficient information, different approaches to interpreting the arm's length principle (e.g., some countries take a more holistic approach and favour profit-based methods while others take a more transactional approach or favour safe harbours ${ }^{65}$ ), and challenges in establishing comparable arm's length prices to the impugned transfer pricing transaction. Even though transfer pricing disputes involve interpretative issues and their outcome affects the allocation of taxing rights between two countries, these disputes ultimately are of numerical or quantitative nature - establishing the arm's length price. Transfer pricing analysis requires a huge amount of data. Data can come to the aid of dispute prevention and resolution.

From a taxpayer's perspective, technology is not only the key element to improve transparency at a global level, as intended by the OECD/G20 BEPS initiative, but also is a mechanism for selfassessment in respect of the information regarding the OECD project to be provided to tax authorities. From the viewpoint of the tax authorities, information gathering as well as data analytics on tax and transfer pricing risks depend greatly on technology. ${ }^{66}$

For example, at the level of identifying the commercial and financial relations, machine learning and deep learning systems can assist MNEs in careful identification of assets, functions, and risk, optimization of the transaction cost, automated characterization of the parties (distributors, manufactures, service providers, property owners, etc.). At the stage of selection and application of the most appropriate transfer pricing method, machine learning and AI technologies can collect the profit level indicators information for the application of the method. At the stage of transfer 
pricing monitoring and tax compliance, AI will enable flexible mapping and simulation of CbCR data, extraction and analysis of that data and XML conversion of the data. If a taxpayer is interested in negotiating an advance pricing agreement, AI may be used to perform automated consideration of critical assumptions, as well as predictive and probabilistic analytics. Blockchains can accompany the application of AI technologies to provide a strong two-edged alliance offering efficiency and security. AI provides high efficiency with the decision-making power, while Blockchain provides utmost security.

Tax administrations can use AI and data analytics to assess compliance risks and determine audit targets. For example, the Chinese STA uses desktop analytics -- the China Tax Information System to select and target taxpayers for scrutiny and audit. The STA relies on transfer pricing disclosure forms and documentation, as well as industry-wide or sector-specific financial data to perform the screening for red flag risk indicators. ${ }^{67}$

In addition to facilitating better transfer pricing compliance and audits, technology is being used in some countries to move toward a new paradigm -- real-time and multilateral transfer pricing assessments. The International Compliance Assurance Programme (ICAP) proposes to use CbCRs and other information such as the Master File, the Local File, value-chain analysis and financial data in respect of reported permanent establishments to enable open and cooperative multilateral engagements between MNE groups and tax administrations in various jurisdictions in performing a multi-jurisdictional risk assessments before any audit is started. ${ }^{68}$ Many tax administrations are reportedly adopting this paradigm shift, replacing traditional post-transactional tax returns and contemporaneous transfer pricing documentation at the year-end with real-time audits. As a result, this new paradigm will likely reduce the relevance of advance pricing agreements or MAP, which occur either before or after the transactions.

With respect to settling transfer pricing disputes between a taxpayer and tax administrations or between competent authorities under the MAP provision, AI/robot-mediated processes can be considered. Since transfer pricing disputes are numerical, Smartsettle ONE type of programs may be used to expedite the process and overcome the problem of lacking expertise or human resources.

Formulary apportionment of global profit has been proposed by the OECD to allocate profits arising from digital businesses. ${ }^{69}$ As of January 2020, over 137 countries and jurisdictions had agreed to participate in the negotiations about the OECD proposals. ${ }^{70}$ If this approach is eventually adopted, one can imagine the critical role of technology in ensuring accuracy and security of data for all countries to rely on in assessing their share of the global profit of an MNE.

\subsection{3 "Measurable” tax disputes}

Some tax disputes involve "measurable" issues, such as the temporal test in defining a service permanent establishment (e.g., a permanent establishment is deemed to exist if the service activity lasts for more six months) or an exemption from source country taxation if an employee stays in the source country for less than 183 days. Presumably, with more reliable data obtained from the taxpayer, third parties (customers or suppliers) and other government agencies (regulatory bodies, border and immigration administration, banks, etc.) can assist the application of the temporal test, thereby reducing tax dispute.

Dual residence disputes can also be potentially measurable. The number of social and economic ties an individual has in both jurisdictions can be quantified and compared by using data available to tax administrations, including information from CRS, Big Data, etc. 
Li et al Digitalization and Dispute Resolution (C2020

Withholding tax disputes may also be measurable. As the Dutch pilot project suggests, the use of Blockchain technology by the payer of fees subject to withholding tax may render tax withholding and reporting automatic, thereby reducing disputes. Digitalised withholding and reporting of digital taxes (such as the Digital Services Tax) may be used for other taxes.

\subsubsection{Interpretative issues}

Improved data transparency and accuracy as well as effective means of communication may help reduce disputes in respect of interpreting tax treaty provisions, such as Article 5 on permanent establishment, the characterization of payments as royalties for withholding tax purposes, the meaning of beneficial ownership or denying treaty benefits by applying anti-abuse rules. However, when human wisdom and decision-making is required to address case-specific issues, the benefit of using technology is likely more limited. Interpretation of tax laws and treaties cannot be mere formalistic. As such, AI is unlikely to replace humans in resolving interpretive issues, even though it can aid tax administrations in reaching effective decisions. ${ }^{71}$

\section{Window of Opportunity for BRITACOM}

\subsection{Unprecedented Opportunity}

BRITACOM has identified expediting dispute resolution and digitalizing tax administration as two main objectives. Digitalizing dispute resolution can not only expedite dispute resolution, but also help raise tax certainty, enhance tax administration capacity and streamline tax compliance. In light of the recent developments canvassed in Part 2 and the potential benefits of digitalization summarized in Part 3, a strong case can be made for BRITACOM to take advantage of the opportunities presented by technology to achieve its objectives. As a new organization, starting a new mechanism in digital format is arguably easier than transforming an existing one. As such, there is an advantage in being new.

With the benefit of global standards for CRS and CbCR, BRITACOM can tap into the existing standards and experiences. BRI jurisdictions also include some of the world leaders in digitalizing tax administration. BRITACOM can help member countries share such successful practices to enhance the capacity of tax administrations. More importantly, perhaps, BRITACOM can bring about the economies of scale through pooling and sharing resources through adopting common technical and administrative standards and purchasing the necessary technologies. There are different models for sharing the cost of digitalization: one can be based on the benefit principle (member countries that benefit more will pay more) ${ }^{72}$ another can be based on the extent of use (or user fee model); ${ }^{73}$ or a private/public partnership model (as the digitalized mechanism will benefit taxpayers as well as tax administrations).

\subsection{Creating A Digitalized Dispute Management Mechanism}

Creating a digitalized dispute management mechanism (DDMM) within BRITACOM may be necessary to achieve the desired objectives. This DDMM can work with other bodies of BRITACOM, such as the Advisory Board and the Belt and Road Initiative Tax Capacity Enhancement Group (BRITACEG). The scope of work for DDMM can include dispute prevention and dispute resolution. DDMM can take advantage of technologies to create online portals, platforms, ODR, registry of tax disputes, among others to assist BRITACOM member tax administrations and taxpayers. 
More specifically, the proposed DDMM can help reduce tax disputes in a number of ways, such as enhancing the capacity of tax administrations in utilizing the available data obtained through taxpayer reporting, big data mining, CRS and CbCR through online training; making tax laws and treaties accessible to taxpayers; sharing best practices or templates for reaching advance pricing agreements; using AI to answer frequent treaty interpretation questions; and adopting cooperative compliance practices with respect to large taxpayers.

To expedite tax dispute resolution, the proposed DDMM can consider recommending the use of robot-mediators in settling tax disputes or reaching agreement by the competent authorities through the MAP process. It can facilitate dispute resolution through creating online portals (similar to eLitigate in Singapore) to aid competent tax authorities in MAP negotiations. If BRITACOM were to establish a dispute resolution board to function as independent arbitration panel or advisory to tax administrations, ${ }^{74}$ the DDMM can support the work of this board.

\section{Conclusion}

The trend of digitalization in tax administration is expected to speed up in Belt and Road jurisdictions. This process may generate more tax disputes when more information is available to tax administrations to assess taxpayers. While the substantive tax rules (domestic and tax treaty) are likely to remain unchanged in the near future because developing a consensus on tax reform is critical but time-consuming, technology may come to the aid of taxpayers and tax administrations to expedite dispute resolution and reduce the number of tax disputes. As a new organization, BRITACOM is uniquely situated to take advantage of the recent developments and create digital solutions. It is hoped that the research evidence presented and suggestions made in this paper can generate some debates about the necessity and feasibility of creating a dispute manage mechanism under BRITACOM.

\footnotetext{
${ }^{1}$ Organization for Economic Co-operation and Development (OECD), Tax Administration 2019: Comparative Information on OECD and Other Advanced and Emerging Economies (Paris: OECD, 2019) (http://doi.ora/10.1787/74d162b6-en) (“OECD, Tax Administration 2019").

2 Belt and Road Initiative Tax Administration Cooperation Forum, "Wuzhen Statement", April, 2019 (http://www.chinatax.gov.cn/eng/n4260859/c5112273/5112273/files/a6466929ab654fbf842d982b0906442e.pdf.) Belt and road countries refer to countries that have signed co-operation agreements with China on the BRI, which was launched by the Chinese President Xi Jinping in 2013. For more information, see https://eng.yidaiyilu.gov.cn/

${ }^{3}$ OECD, Tax Administration 2019, supra note 1, at 32. See also OECD, Technologies for Better Tax Administration: A Practical Guide for Revenue Bodies (Paris: OECD, 2016) (https://www.oecd.org/publications/technologies-for-better-tax-administration9789264256439-en.htm).

${ }^{4}$ OECD, Statement by the OECD/G20 Inclusive Framework on BEPS on the Two-Pillar Approach to Address the Tax Challenges Arising from the Digitalisation of the Economy: As approved by the OECD/G20 Inclusive Framework on BEPS on 29-30 January 2020 (Paris: OECD, 2020), 137 countries joining in the talk on digital taxation (https://www.oecd.org/tax/beps/statement-bythe-oecd-g20-inclusive-framework-on-beps-january-2020.pdf); OECD, OECD Secretary-General Tax Report to G20 Finance Ministers and Central Bank Governors (Paris: OECD, Oct. 2019) (http://www.oecd.org/ctp/oecd-secretary-general-tax-report-g20finance-ministers-riyadh-saudi-arabia-february-2020.pdf); also see OECD/G20 Inclusive Framework on BEPS (https://www.oecd.org/tax/beps/).

${ }^{5}$ Big Data can be labelled as descriptive analytics, consisting of analysing large data sets to derive trends and patterns from a descriptive standpoint. There is also predictive analytics to understand what is likely to happen (modelling and tread detection) and prescriptive analytics (use of predictive models to determine the best course of action).
} 
${ }^{6}$ Blockchain is a shared, immutable and distributive ledger technology for recording transactions, tracking assets and building trust.

${ }^{7} \mathrm{Al}$ is often used to describe computers that mimic cognitive functions that humans associate with the human mind, such as "learning" and "problem solving".

${ }^{8}$ Machine learning can be understood as a form of Al that enables a system to learn from data.

${ }^{9}$ OECD, Tax Challenges Arising from Digitalisation-Interim Report 2018: Inclusive Framework on BEPS (Paris: OECD, March 2018) at 13.

10 OECD, Tax Administration 2019, supra note 1 at 201.

${ }^{11}$ Bas Jacobs, "Chapter 2: Digitalization and Taxation”, in Sanjeev Gupta, Michael Keen, Alpa Shah, and Genevieve Verdier eds, Digital Revolutions in Public Finance (International Monetary Fund, 2017) ("IMF Report")

(https://www.elibrary.imf.org/view/IMF071/24304-9781484315224/24304-

9781484315224/ch02.xml?language=en\&redirect=true).

${ }^{12}$ Forbesinsights, Digital Taxation: How Businesses Are Responding to the New Wave in Global Tax Compliance (2019) (http://info.forbes.com/rs/790-SNV-353/images/Sovos_eBook_FINAL-WEB.pdf).

${ }^{13}$ See OECD, Tax Administration 2019, supra note 1; Intra-European Organisation of Tax Administrations, Disruptive Business Models: Challenges and Opportunities for Tax Administrations (2017) (https://www.iota-

tax.org/sites/default/files/publications/public_files/disruptive-business-models.pdf) (“IOTA Report”); Forbes, "Global Taxation is Going Digital: Here's How to Prepare" (2019) (https://www.forbes.com/sites/insights-sovos/2019/04/18/global-taxation-is-goingdigital-heres-how-to-prepare/\#10a3b46d4fd3); and Forbesinsights, ibid.

${ }^{14}$ See Gerli Jogi, "Digitisation and Organisational Changes in Estonian Tax and Customs Board” in IOTA Report, ibid., at 56-8.

${ }^{15}$ Steef Hubregtse, Paola Ottoni, and Sonia Catalina Munoz Rodrguez, "How Technology is Changing Taxation in Latin America" (2019) 73:3 Bulletin for International Taxation 141-52, at 146.

16 Jingnan Chen, Shaun Grimshaw and Gareth Myles, “Chapter 5: Testing and Implementing Digital Tax Administration"in IMF Report, supra note 11.

17 See Chen Jia, "Tax deduction app goes online" (Jan. 2, 2019) China Daily (https://www.chinadaily.com.cn/a/201901/02/WS5c2c04ffa310d91214051f69.html).

${ }^{18}$ OECD, Tax Administration 2019, supra note 1, at 43-4.

${ }^{19}$ Sam Webb, "Blockchain invoices hit 10 million in China tech hub" https://finance.yahoo.com/news/blockchain-invoices-hit-10million-210032961.html (accessed Feb 12, 2020); also see "More than 10 million Blockchain invoices are issued in Shenzhen", November 1, 2019, Xin Hua Newsnet (“深圳区块链电子发票突破 1000 万张”, 新华网)

(http://www.xinhuanet.com/fortune/2019-11/01/c_1125179454.htm)

${ }^{20}$ Sanjeev Gupta, Michael Keen, Alpa Shah, and Genevieve Verdier, "Chapter 1: Introduction Reshaping Public Finance" in IMF Report, supra note 11 , at 4.

${ }^{21}$ OECD, Tax Administration 2019, supra note 1, at 63.

${ }^{22}$ Gerard Blankestijn, "Blockchain - new roles and ways of interaction: A proof of concept on payroll tax" in IOTA Report, supra note 13 at 41-3. See also OECD, The Sharing and Gig Economy: Effective Taxation of Platform Sellers (Paris: OECD, 2019) (http://www.oecd.org/ctp/the-sharing-and-gig-economy-effective-taxation-of-platform-sellers-574b61f8-en.htm).

${ }^{23}$ Blankestijn, ibid.

${ }^{24}$ Aqib Aslam and Alpa Shah, "Chapter 3: Taxation and the Peer-to-Peer Economy" in IMF Report, supra note 11 , at 86.

${ }^{25}$ Stephen Chen, "China Prepares to unleash artificial intelligence to catch tax cheats", South China Morning Post (24 December, 2019), https://amp-scmp-com.cdn.ampproject.org/c/s/amp.scmp.com/news/china/science/article/3043437/china-prepares-unleashartificial-intelligence-catch-tax-cheats.

${ }^{26}$ OECD, Tax Administration 2019, supra note 1, at 48. 
${ }^{27}$ Ibid., at 50.

${ }^{28}$ Ibid., at 55.

${ }^{29}$ For more information, see Global Forum on Transparency and Exchange of Information for Tax Purposes at https://www.oecd.org/tax/transparency/technical-assistance/aeoi/whatisthemultilateralcompetentauthorityagreement.htm

30 OECD, "Automatic Exchange Portal” (https://www.oecd.org/tax/automatic-exchange/common-reporting-standard/schema-anduser-guide/). Both FATCA and CRS requires data to be recorded in Extensible Markup Language (XML) format, following a XML Schema. XML is a markup language developed in 1998 and is simply the structure by which the data is stored. The Schema is the order in which the data must be reported, creating a "reporting pattern" to be followed by all countries when creating the exchangeable files. This format was designed to store and transport data between computers and/or datacenters and is broadly used these days without incurring substantial additional costs. The CRS XML Schema can be downloaded from the OECD website.

${ }^{31}$ The CbC XML Schema User Guide further explains the information required to be included in each data element to be reported. It also contains guidance on how to make corrections of data element within a file. See OECD, Country-by-Country Reporting XML Schema: User Guide for Tax Administrations (Paris: OECD, 2019) (https://www.oecd.org/ctp/exchange-of-taxinformation/country-by-country-reporting-xml-schema-user-guide-for-tax-administrations.htm).

${ }^{32}$ See OECD BEPS Inclusive Framework on Base Erosion and Profit Shifting, "Action 13 Country-by-Country Reporting" (http://www.oecd.org/tax/beps/beps-actions/action13/); OECD, Guidance on the Implementation of Country-by-Country Report, BEPS Action 13 (Paris: OECD, 2019) (https://www.oecd.org/ctp/guidance-on-the-implementation-of-country-by-countryreporting-beps-action-13.pdf).

33 Jefferey Owens remarked that a "tax disputes tsunami" may be coming; see J. Kollman, P. Koch, A. Majdanska and L. Turcan, "Arbitration in International Tax Matters," Tax Notes International 77, 1189-95. See also Owen's paper in Michael Lang \& Jeffrey Owens eds, International Arbitration in Tax Matters (Amsterdam: IBFD, 2015) 157-167 at 159.

${ }^{34}$ See Joint Technology Committee, Case Studies in ODR for Courts: A view from the front lines (29 November 2017), JTC Resource Bulletin, (https://www.ncsc.org/ /media/files/pdf/about\%20us/committees/jtc/jtc\%20resource\%20bulletins/201712-18\%20odr\%20case\%20studies\%20final.ashx). See Ontario Superior Court of Justice, Digital Hearing Workspace User Guide, March 29, 2019 (https://www.ontariocourts.ca/scj/files/forms/com/dhw/DHW-UserGuide-EN.pdf).

${ }^{35}$ See Ontario Superior Court of Justice, ibid.

${ }^{36}$ See Supreme Court, Singapore, https://www.supremecourt.gov.sg/services/services-for-the-legal-profession/elitigation.

${ }^{37}$ See https://mkri.id/.

38 Supreme Court Regulation 1/2019 on Electronic Administration of Cases and Hearings in the Court System and Chief Justice's Directive 129/KMA/VIII/2019 on Technical Guidelines for Electronic Administration of Court Cases and Hearings.

${ }^{39}$ For further, see https://www.kratid.ee/in-english; https://www.wired.com/story/can-ai-be-fair-judge-court-estonia-thinks-so/; https://www.thelawyersdaily.ca/articles/12997/from-estonian-ai-judges-to-robot-mediators-in-canada-uk-?article_related_content $=1$

${ }^{40}$ See Derek Thompson, "Should We Be Afraid of Al in the Criminal-Justice System? Many states and cities are putting Americans' fates in the hands of algorithms", The Atlantic, June 20, 2019 (this practice "may be nothing more than mathematical expressions of underlying bias" https:/www.theatlantic.com/ideas/archive/2019/06/should-we-be-afraid-of-ai-inthe-criminal-justice-system/592084/). See also Karen Hao, "Al is sending people to jail -and getting it wrong", MIT Technology Review, Jan.21, 2019(https://www.technologyreview.com/s/612775/algorithms-criminal-justice-ai/); and Michael E. Donohue, "A Replacement for Justitia's Scales? Machine Learning's Role in Sentencing" (2019) 32:2 Harvard Journal of Law \& Technology 657-78.

${ }^{41}$ Briony Harris, "Could an Al ever replace a judge in court?" July 11, 2018, World Government Summit (https://www.worldgovernmentsummit.org/observer/articles/could-an-ai-ever-replace-a-judge-in-court).

$42 \mathrm{See}$, for example, China Council for the Promotion of International Trade/China Chamber of International Commerce adopted China International Economic and Trade Arbitration Commission Online Arbitration Rules on January 8, 2009, see https://uncitral.un.org/en/library/online resources/online dispute resolution. 


\footnotetext{
${ }^{43}$ See e.g. EU, Directive 2013/11/EU of the European Parliament and of the Council of 21 May 2013, Official Journal of the European Union L165; UNCITRAL, Technical Notes on Online Dispute Resolution (New York: UN, 2017).

44 "Claimants, respondents and arbitral panelists all have web-based access to all of the digitized materials. At the same time, each party retains secure, private access to internal attorney work product, including notes, tags, research, private documents and so on. Parties can perform quick searches of the data set at any time. They can also annotate, categorize and organize documents into custom binders, and share mark-up and commentary among designated users." Charlie Harrel, "The Digital Future Of Arbitration" (2017) Plaintiff Magazine (https://www.plaintiffmagazine.com/recent-issues/item/the-digital-future-ofarbitration).

45 Lise Alm, "The SCC Platform"( https://journal.arbitration.ru/analytics/the-scc-platform/).

${ }^{46}$ See https://uncitral.un.org/en/texts/arbitration/contractualtexts/arbitration.

${ }^{47}$ See https://iccwbo.org/dispute-resolution-services/arbitration/rules-of-arbitration/.

${ }^{48}$ Asia-Pacific Economic Cooperation, APEC Collaborative Framework for Online Dispute Resolution of Cross-Border Business-toBusiness Disputes - Endorsed, 26-27 August 2019 (http://mddb.apec.org/Documents/2019/EC/EC2/19 ec2 022.pdf).

49 Ibid., section 1.2 .

${ }^{50}$ See https://go.smartsettle.com/. For more on this particular case, see Graham Ross, "Smart settlement: an opportunity for mediators", Infolaw newsletter, March 2019 (https://www.infolaw.co.uk/newsletter/2019/03/smart-settlement-opportunitymediators/); and John Hyde, "Mediator claims online dispute first to be settled by algorithm", The Law Society Gazettle, 25 February 2019 (https://www.lawgazette.co.uk/news/mediator-claims-online-dispute-first-to-be-settled-by-algorithm15069393.article).

${ }^{51}$ Tara Vasdani, “From Estonian Al Judge to robot mediators in Canada, U.K." The Lawyer's Daily, June 13, 2019 (https://www.thelawyersdaily.ca/articles/12997).
}

${ }^{52}$ Article 25 of the UN Model has two alternatives: Alternative A reproduces Article 25 of the OECD Model without paragraph 5 regarding arbitration and Alternative $B$ includes the arbitration clause with some modifications.

${ }^{53}$ E.g. UN Model, Annex to the commentary on paragraph 5 of article 25, at 611 and 612.

${ }^{54}$ Christina Dimitropoulou, Sriram Govind and Laura Turcan, "Applying modern, disruptive technologies to improve the effectiveness of tax treaty dispute resolution" (2018) eJournal of Tax Research at 287.

55 E.g. Rob Thomas, Becky Lai and Justin Kyte, “Discussion Paper on Improving Dispute Settlement among 'Belt and Road' Jurisdictions" in BRITACOM Special Edition, Building a Growth-Friendly Tax Environment in Collaboration with International Taxation in China (April 2019), at 80-91 (hereinafter "Thomas, Lai and Kyte"); Hunan Tax Bureau of State Administration of Taxation and PwC, Guidelines of Tax Policy and Risk Management under Belt and Road Initiative (forthcoming). (湖南国税局, 普华永道, 《一带一路一税收政策与风险管理手册》); Xiaojing Cui, “Research on Preferential Arrangement and Dispute Resolution under Tax Treaties between China and 'the Belt and Road' Countries” (2017) 2 China Legal Science 194-214 (崔晓 静, 《中国与“一带一路”国家税收协定优惠安排与适用争议研究》, 载《中国法学》, 2017 年 2 期, 第 194-214 页); Xu Diheng, "A Step Forward for Tax Dispute Resolution between China and ASEAN Countries under the Belt and Road Initiative" (2019) 7:1 Singapore Management University School of Accountancy Research Paper, No. 2019-S-93 (https://ssrn.com/abstract=3349398).

56 Thomas, Lai and Kyte, ibid.

57 OECD, "MAP statistics" (https://www.oecd.org/tax/dispute/mutual-agreement-procedure-statistics.htm).

${ }^{58}$ Supra note 55 .

${ }^{59}$ For further, see Sanjeev Gupta et. al. "Chapter 1: Introduction Reshaping Public Finance" and Susan Lund, Olivia White, and Jason Lamb, "Chapter 13: The Value of Digitalizing Government Payments in Developing Economics" in IMF Report, supra note 11.

${ }^{60}$ Lund et. al., ibid., at 305.

${ }^{61}$ See https://www.worldbank.org/en/programs/platform-for-tax-collaboration. 
62 Thomas, Lai and Kyte, supra note 55, report the results of a survey that grouped corporations according to their size: Group A includes large corporations, having an average annual revenue of approximately USD 83 billion engaged in sectors such as oil and gas, manufacturing, digital, financial services, telecommunications, infrastructure, and electronics; Group B includes somewhat smaller corporations, having an average annual revenue of approximately USD 3 billion and doing business in manufacturing, services, design and engineering as well as infrastructure.

${ }^{63}$ For example, the IRS is engaging in data mining of public and commercial data pools (including social media) and creating highly detailed profiles of taxpayers upon which to run data analytics. See Kimberly A. House and Debra Sanders, "The use of Big Data Analytics by the IRS: Efficient Solutions or the End of Privacy as We Know it?" (2017) 19:4 Vanderbilt Journal of Entertainment \& Technology Law 817-72.

${ }^{64}$ See Heading 3.1 above.

${ }^{65}$ For general, see OECD, Transfer Pricing Guidelines for Multinational Enterprises and Tax Administrations (Paris: OECD, 2017) (https://www.oecd.org/tax/transfer-pricing/oecd-transfer-pricing-guidelines-for-multinational-enterprises-and-taxadministrations-20769717.htm); UN, Practical Manual on Transfer Pricing (New York: UN, 2013) "Chapter 10, Country Practices" (https://www.un.org/esa/ffd/wp-content/uploads/2014/08/UN_Manual_TransferPricing.pdf).

${ }^{66}$ Hubregtse et. al., supra note 15, at 142.

${ }^{67}$ Ibid., at 147.

${ }^{68}$ See https://www.oecd.org/tax/forum-on-tax-administration/international-compliance-assurance-programme.htm.

${ }^{69}$ See OECD, "Webcast: Update on Economic Analysis and Impact Assessment" (https://www.oecd.org/tax/beps/webcasteconomic-analysis-impact-assessment-february-2020.htm).

70 "137 countries on board for OECD digital tax plan: Angela Gurria", The Economic Times, Jan. 23, 2020 (https://economictimes.indiatimes.com/news/international/business/137-countries-on-board-for-oecd-digital-tax-plan-angelagurria/articleshow/73556237.cms?from=mdr).

${ }^{71}$ Similar reasons explain why arbitration is not available to interpretative disputes and has been used primarily in transfer pricing cases.

72 This is similar to the World Trade Organisation (WTO) model. The WTO derives its income from annual contributions from its 164 members and miscellaneous income. These contributions are based on a formula that takes into account each member's share of international trade. Miscellaneous income mainly consists of contributions from observer countries, income from the sale of publications and rental of meeting rooms. See WTO, Annual Report 2019

(https://www.wto.org/english/res_e/booksp_e/anrep_e/anrep19_chap9_e.pdf) at 172-80.

${ }^{73}$ This is similar to the International Centre for Settlement of Investment Disputes (ICSID) model. ICSID's administrative expenditures in FY2019 were covered by fee income and by the International Bank for Reconstruction and Development (IBRD) pursuant to the Memorandum of Administrative Arrangements concluded between the IBRD and ICSID. Expenditures relating to pending arbitration proceedings are borne by the parties in accordance with ICSID's Administrative and Financial Regulations. See ICSID, Annual Report 2019 (https://icsid.worldbank.org/en/Documents/ICSID_AR19_EN.pdf)

${ }^{74}$ Jinyan Li, Jin Bao, Shanghua Hu and Wei Hu, “Arbitration of International Tax Disputes and 'Belt \& Road Initiative': the Limitation of Baseball Arbitration” (2020) International Taxation in China (forthcoming) (李金艳，包晋，胡尚华，胡巍， 《国 际税务仲裁与“一带一路”: 棒球游戏的局限性》, 载《国际税收》, 2020 年第 4 期). 